\title{
MICROMORPHOLOGY AND HISTOCHEMICAL TRAITS OF STAMINAL OSMOPHORES IN ASPHODELUS AESTIVUS BROT. FLOWER
}

\author{
Elżbieta Weryszko-Chmielewska ${ }^{1}$, Mirosława Chwil ${ }^{1}$, Thomas Sawidis ${ }^{2}$
}

\author{
${ }^{1}$ Department of Botany, Agricultural University of Lublin, 20950 Lublin, Akademicka 15, Poland \\ e-mail: elzbieta.weryszko@.ar.lublin.pl \\ ${ }^{2}$ Department of Botany, University of Thessaloniki, GR - 54006 Thessaloniki, Greece
}

Received: 10.01.2007

S u m m ary

The conducted studies pertained to micromorphology of the surface of epidermis cells and histological traits of staminal filaments of Asphodelus aestivus Brot. flowers. The structure of the filaments was analyzed in a light microscope (LM) using various histochemical techniques. The morphology of the surface of the epidermis of filaments was observed in scanning electron microscope (SEM).

Filaments Asphodelus aestivus accrete together with the basal part of the abaxial surface with the leaves of perianth. Their lower, wider, and flattened part surrounds the ovary. The epidermis of the staminal osmophores creates papilliose cells and unicellular hairs of various sizes. In the uppermost part of these structures, round marks in the cuticle layer after the emission of discharge were observed with the SEM. The outside, convex wall of the isodiametric cells of the epidermis, papillae and hairs was significantly thicker from the remaining walls. It was covered with cuticle of different ornamentation. The cells that created papillae and hairs had a large, centrally located vacuole and a thin layer of cytoplasm with numerous small vacuoles as well as large, often lobed nuclei. In the protoplasts of these cells the presence of plastids and lipid droplets was noted. During the time of secretion of elicitor between the wall and cuticle of the epidermis cells, convex bubbles were formed, in which the secreted substance was accumulated. At the end of secretion, on the surface of papillae, hairs and other cells of the epidermis, irregularly protruding cuticle was observed. It was noted that the composition of staminal osmophores in the flowers of Asphodelus aestivus includes papillae, hairs and cells of the epidermis that do not form papillae.

Key words: osmophores, structure, flowers, filaments, scent emis sion, epidermis, hairs, papillae, Asphodelus aestivus

\section{INTRODUCTION}

It is very probable that the scent plays a key role in the release of instinct responses in animals, especially in insects. Fragrance is considered to be a secondary flower attractant, which is older than the visual stimuli (Faegri and Van der Pij1, 1971). Scent facilitates the distinguishing of appropriate flowers and finding of food for insects (Lex, 1954).

Most commonly, the flower scent is created in the specific plant glands called osmophores (Vogel, 1990). According to this author, osmophores may be defined as ,a histologically localized, multicellular, externally exposed, glandular epithelium in the floral domain, which, along with a mostly rapid and noticeable utilization of reserve materials, during a short period, produces volatile secretions as attractants for pollinators". Considering function and histology, we can distinguish in them the outside emission layer (epidermis) and subepidermal „production layer” (parenchyma). These multi-layered osmophores were observed in various plants species (Stern et al. 1987; Vogel, 1990; Stpiczyńska, 1993; Teixeira et al. 2004). Sometimes the osmophore function is fulfilled only by epidermis (Voge 1, 1990; Raguso and Pichersky, 1999; Effmert et al. 2005).

Osmophores can be found most commonly in certain petal fragments or tepals of perianth, which was found in many species (Esau, 1973; Stern et al. 1987; Slater and Kalder, 1988; Vogel, 1990; Stpiczyńska, 1993, 2001; Kolosova et al. 2001) or on the surface of spadix and spatha at Araceae (Vogel, 1990; Weryszko-Chmielewska and Stpiczyńska, 1995). It was also shown that the osmophores can be located in the connectives of stamens in Solanum (Passarelli and Brudzone, 2004) as well as in the receptacle, in the connectives and appendages in Nelumbo (Vogel and Hadacek, 2004).

The secretive epithelium of the osmophores can be composed of flat cells as well as those with convex outside walls of epidermis (Stern et al. 1987; Vogel, 1990), of papilliose cells (Vogel, 1990; 
Kolosova et al. 2001; Teixeira et al.2004; Vogel and Hadacek, 2004) or unicellular hair of various shapes: clavate, semispherical, sucker-like or conical (Vogel, 1990; Stpiczyńska, 1993, 2001).

The aim of the work was to determine the micromorphology as well as structure and function of hairs of the filaments of Asphodelus aestivus, with various histochemical tests.

\section{MATERIAL AND METHODS}

The studies pertained to micromorphology of the of cells of epidermis and histological traits of filaments Asphodelus aestivus Brot. This ornamental plant belongs to Asphodelaceae family. The plant material originated from an area approximately $25 \mathrm{~km}$ southwest of Larissa, Thessaly, Central Greece. For the studies, flower buds of different age were sampled. From the top, middle and basal sections of the widened parts of filaments, preserved in $4 \%$ glutaraldehyde, cross-sections were made. The presence of lipid substances was analysed after treatment with Sudan III and Sudan black B. The presence of starch was detected with Lugol's solution (IKI), and the components of the cell wall were studied with safranine and by using PAS reaction (Nevalainen et al. 1972). For the determination of general histological characteristics, the toluidyne blue $\mathrm{O}$ was used.

The anatomy of filament was analyzed in light microscope based on semi-stable (embedded in glycerogelatine) and semi-thin, stable preparations, which were formed using the previously described method (Weryszko-Chmielewska et al. 2006).

The micromorphology of the surface of the epidermis of filaments was observed in scanning electron microscope (SEM). Fragments of filaments were preserved in $4 \%$ glutaraldehyde in $0.1 \mathrm{M}$ phosphate buffer $(\mathrm{pH} 7.0)$ for 4 hours in room temperature. Next, after dehydrating the samples of plant material in alcohol series and acetone, they were dried in critical point in liquid $\mathrm{CO}_{2}$ and coated with gold.

\section{RESULTS}

Stamens of Asphodelus aestivus accrete with the basal part of the abaxial surface of filaments with the tepals of perianth (Fig. 1A). The lower part of filaments is widened and flattened (Fig. 1A, B). They surround the ovary, protecting the outlets of septal nectary. The surface of flattened staminal filaments is covered with epidermis which produces various cells: isodiametric on the cross-section, papillose cells and unicellular hairs of various size and shape (Figs. 1A-D; 2A-D; 7A). The largest club-shape hairs (approximately $170 \mu \mathrm{m}$ ), were present on the edges of the flattened fragments of filaments (Figs. 1C, D; 2D; 4A, B). Closer to the axis of the filaments were the isodiametric cells of epidermis with convex outside wall (Fig. 1D) and vesicular and cone shaped papillae (Figs. 2A, B; 3A). On the surface of papillose cells was cuticle with striped ornamentation (Fig. 2B), while the hairs were covered with cuticle with a sculpture of irregularly distributed wrinkles (Fig. $2 \mathrm{E}, \mathrm{F})$. In the top part of some of the hairs and papillae round flattened areas were observed, which probably mark breaking of the cuticle after emission of the previously accumulated elicitor (Fig. 2B C, E).

In the parenchyma of the filament large intercellular spaces occur, especially in the case of subepidermal layers (Figs. 3A, C; 4A-C). The centrally located vascular bundle was surrounded by closely layered cells of the parenchyma (Fig. 3A). In the cells of the epidermis and the subepidermal layers after treating them with Lugol's solution, the presence of starch was not observed.

The outside, convex wall of the isodiametric cells of epidermis, papillae and hairs was considerably thicker than the remaining walls of these cells and it reached on average $4.40 \mu \mathrm{m}$ (Figs. 3B, C, G; 4B-F). From the PAS reaction it can be seen that the wall was derived from cellulose (Fig. 3D), and treating with safranine did not indicate a presence of lignin (Fig. $3 \mathrm{H}$ ). In the walls of neighboring cells of epidermis (Fig. 7C) and between cells of epidermis and parenchyma pits were observed (Fig. 7D, E), which is a characteristic trait of osmophores.

The cross-sections of the hairs had round (Fig. 3D, F) or oval (Fig. 7E) shapes. It was found that on the longitudinal cross-sections the central part of the club-shaped hairs and papillae was filled usually by one vacuole, around which there was cytoplasm which created a rather thin layer (Figs. 3G; 4C-F). In the cytoplasm, also small numerous vacuoles were observed (Figs. 3H-J; 4G-I), which gradually increased in size (Fig. 4J). Significantly enlarged nuclei $(31 \mu \mathrm{m})$ in relation to the nuclei in the parenchyma $(12 \mu \mathrm{m})$ were usually located half way lengthwise in the club-shaped hairs and papillae (Figs. 3G, H; 4E, F). In the case of the isodiametric cells of the epidermis, the nuclei were located near the outside (Fig. 6D; F-H) or the inside (Fig. 6B) tangential wall. Lobed nuclei were often observed (Figs. 6B; $\mathrm{F} ; \mathrm{EE}$ ). In some of the cells, the nuclei were divided into parts (Fig. 7A, B, D). In the cytoplasm, numerous, small plastids were observed (Figs. 3G; 4E).

In the lipid secretion of the elicitor, which was colored in orange by Sudan III and dark blue by Sudan B, participated also hairs and papillae (Figs. 5 B-J; 6I), as well as the epidermal cells without appendages (Figs. 5A; 6A-H). After treating with Sudan III the cuticle also colored orange, revealing the characteristic ornamentation.

At the time of secretion between the wall and cuticle of the epidermal cells there were vesicular convex areas, in which the lipid substance accumulated (Figs. 5 A-D, I, J; 6 C-H). After treating with 

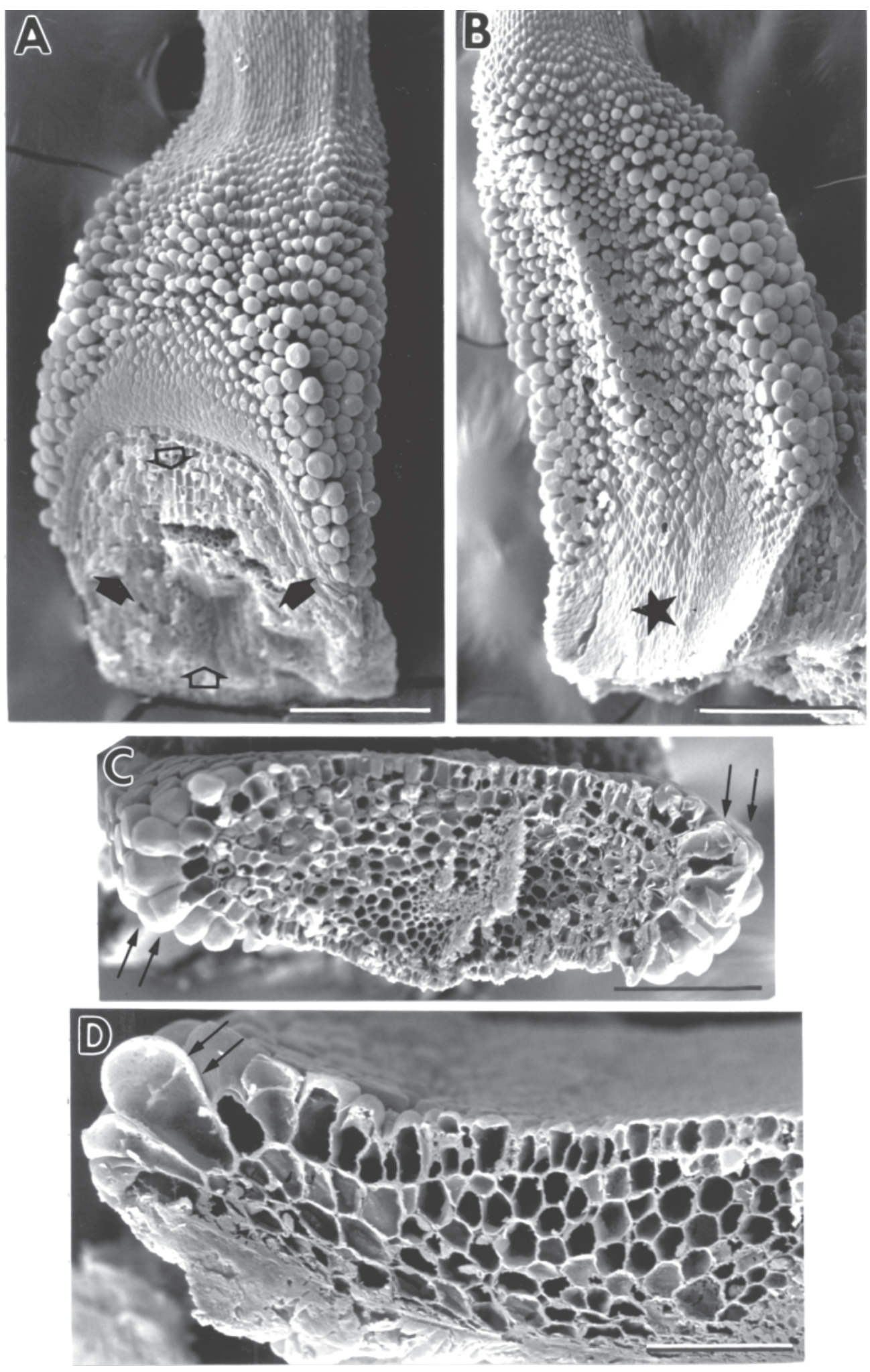

Fig. 1, A D. Lower, wider and flattened part of Asphodelus aestivus filaments (SEM). A Abaxial surface showing the point of attachment with the tepal (arrows); B Adaxial surface with dense growing hairs of different size and smooth surface of epidermis at the ovary base (asterisk); C, D Cross sections of lower part of the filament, at the edge unicellular, club shape hairs (double arrows) are visible. A, B bars $400 \mu \mathrm{m}$; C bar $200 \mu \mathrm{m}$; D bar $80 \mu \mathrm{m}$. 

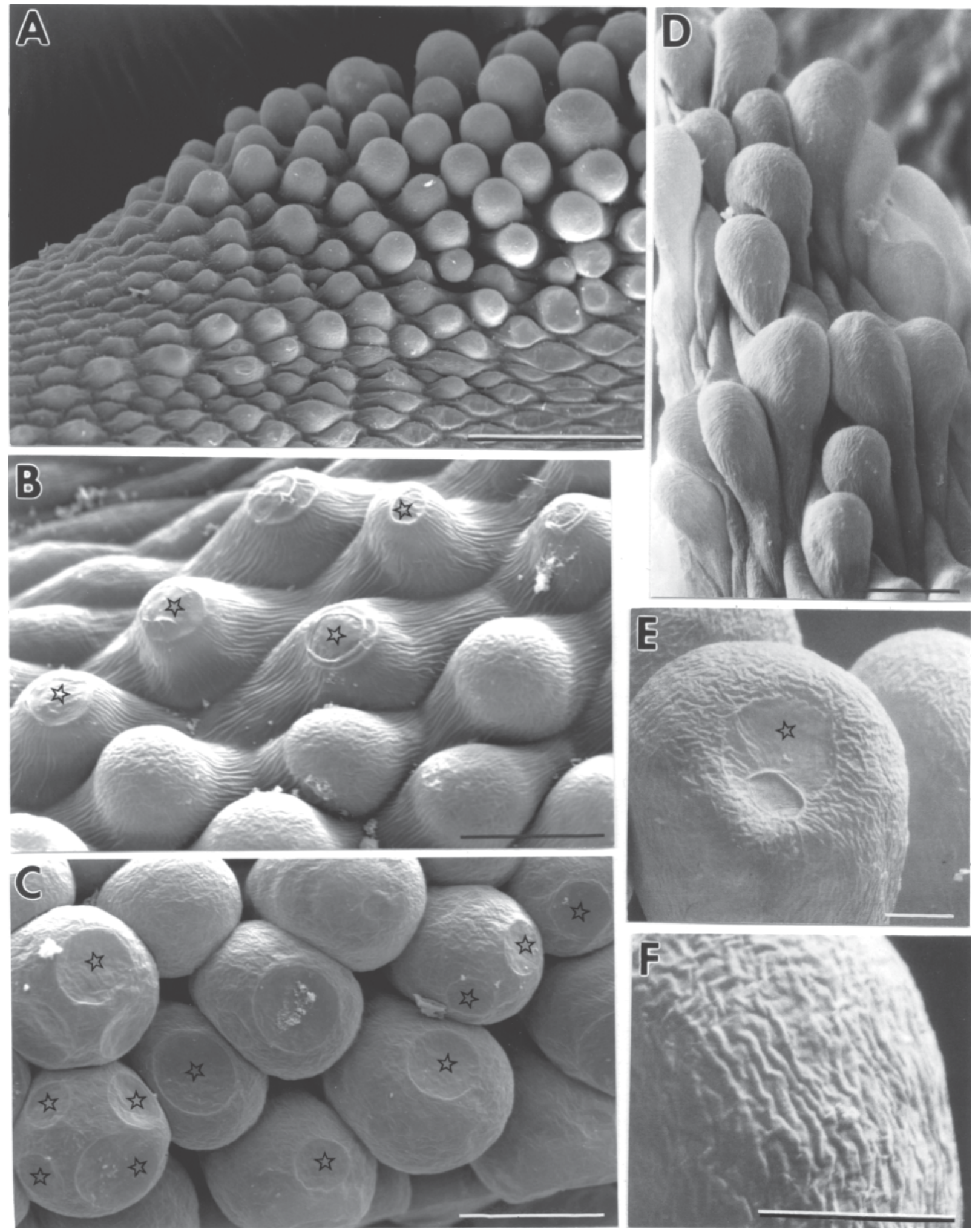

Figs. 2, A F. Fragments of epidermis surface of the basal part of Asphodelus aestivus filaments (SEM). A Hairs and papillae of the different size; B Papillae of conical and blister shape, visible striated cuticle and circular traces on the top after emission of secretion (asterisk); $\mathrm{C} \quad \mathrm{F}$ Club shaped hairs, visible circular traces after emission of secretion (asterisk) $\left(\begin{array}{lllll}C & \text { E) and cuticle with the irregular wrinkles (D } & \text { F). }\end{array}\right.$ A bar $100 \mu \mathrm{m}$; B, D, F bars $50 \mu \mathrm{m}$; C bar $60 \mu \mathrm{m}$; E bar $20 \mu \mathrm{m}$. 

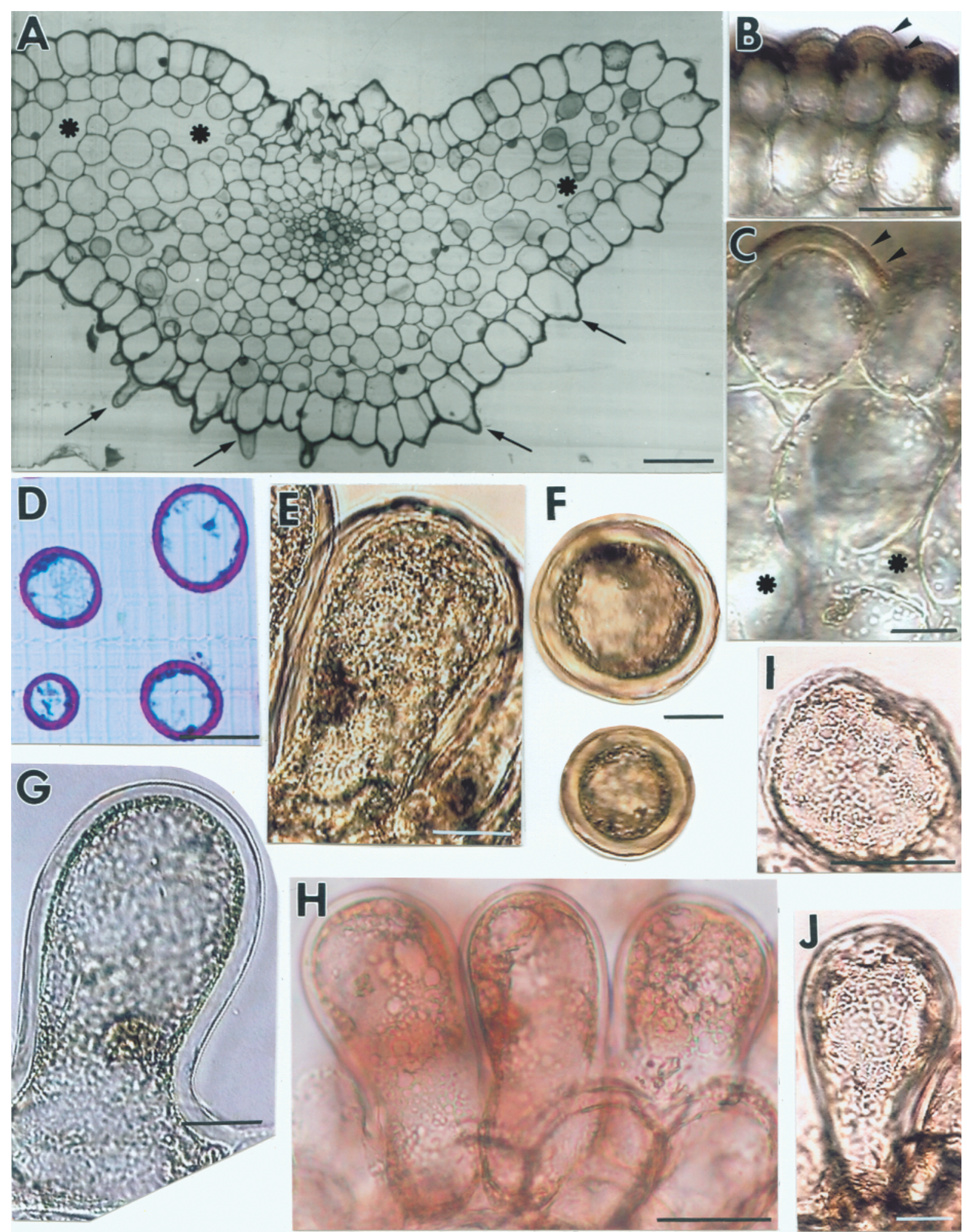

Figs. 3, A H. Fragments of the cross sections of the wider Asphodelus aestivus filament. A Cross section with visible papilliose cells (arrows) and large intercellular spaces in parenchyma (asterisk); B, C Epidermis cells with the thick outer walls (arrow heads) and parenchyma with the large intercellular spaces (asterisk); D, F Cross sections of the hairs; E, G J Glandular hairs on the longitudinal sections, visible thick cell walls and numerous small vacuoles in cytoplasm (H J). Treatment: B, C, G Sudan III; D PAS reaction; E, F, I, J Lugol solution; H safranin. A bar $100 \mu$ m; B, D, H J bar $50 \mu \mathrm{m} ; \mathrm{C}, \mathrm{E}, \mathrm{F}$ bar $20 \mu \mathrm{m} ; \mathrm{G}$ bar $30 \mu \mathrm{m}$. 

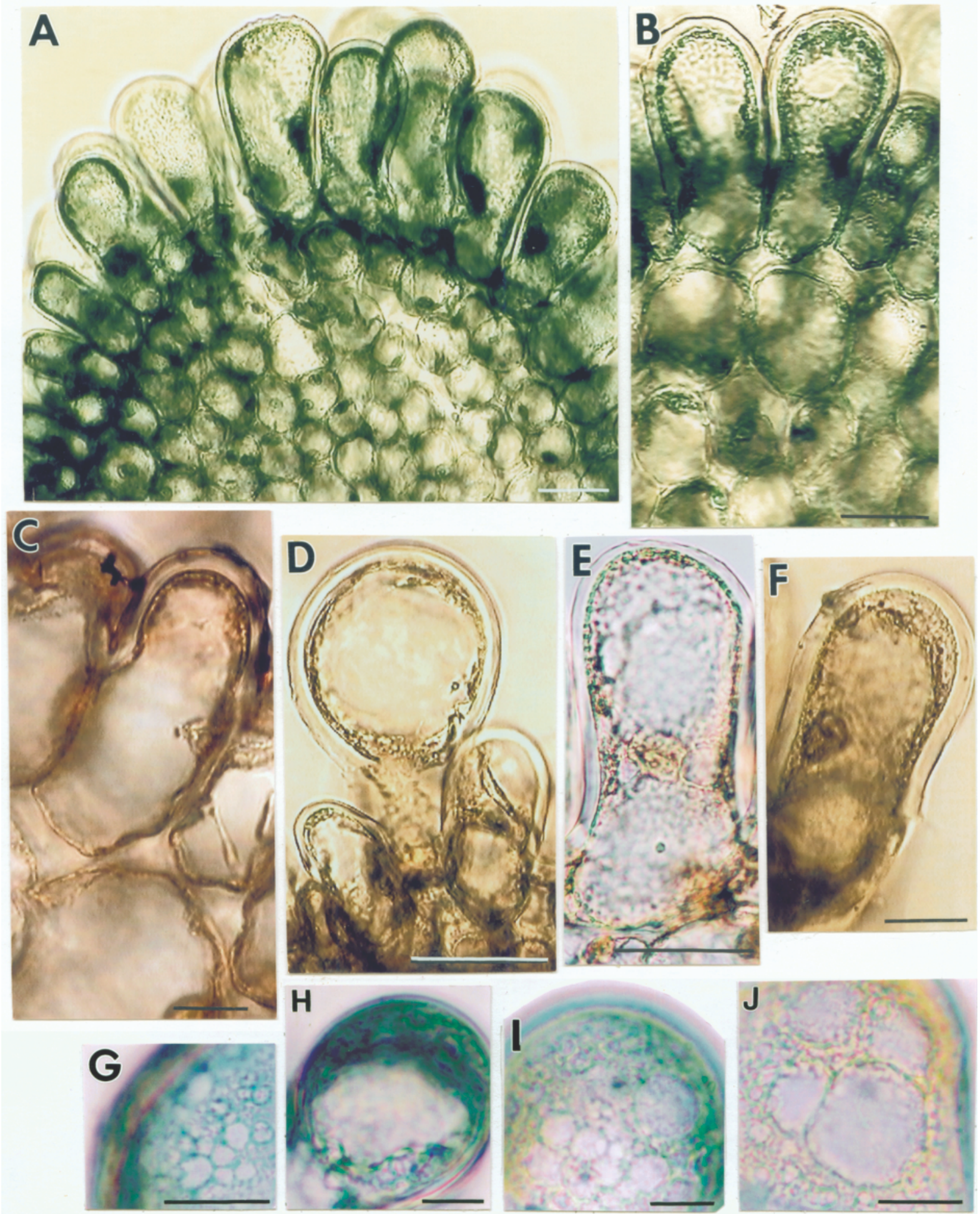

Fig. 4, A F. Fragments of the cross sections of the filament. A, B In epidermis visible unicellular hairs of different size, nuclei of hairs are bigger than nuclei in parenchyma cells. C Papillae with thicker outer wall than other walls; D F Unicellular hairs with thick cell walls, large central vacuoles; in cytoplasm visible small chloroplasts (E); G J Fragments of the hairs with small vacuoles in cytoplasm. Treatment: A, B toluidine blue; C, E Sudan III; D, F Lugol solution; G J Sudan black B. A, B, D F bars $50 \mu \mathrm{m}$; C, H bars $20 \mu \mathrm{m}$; G, I, J bars $10 \mu \mathrm{m}$. 


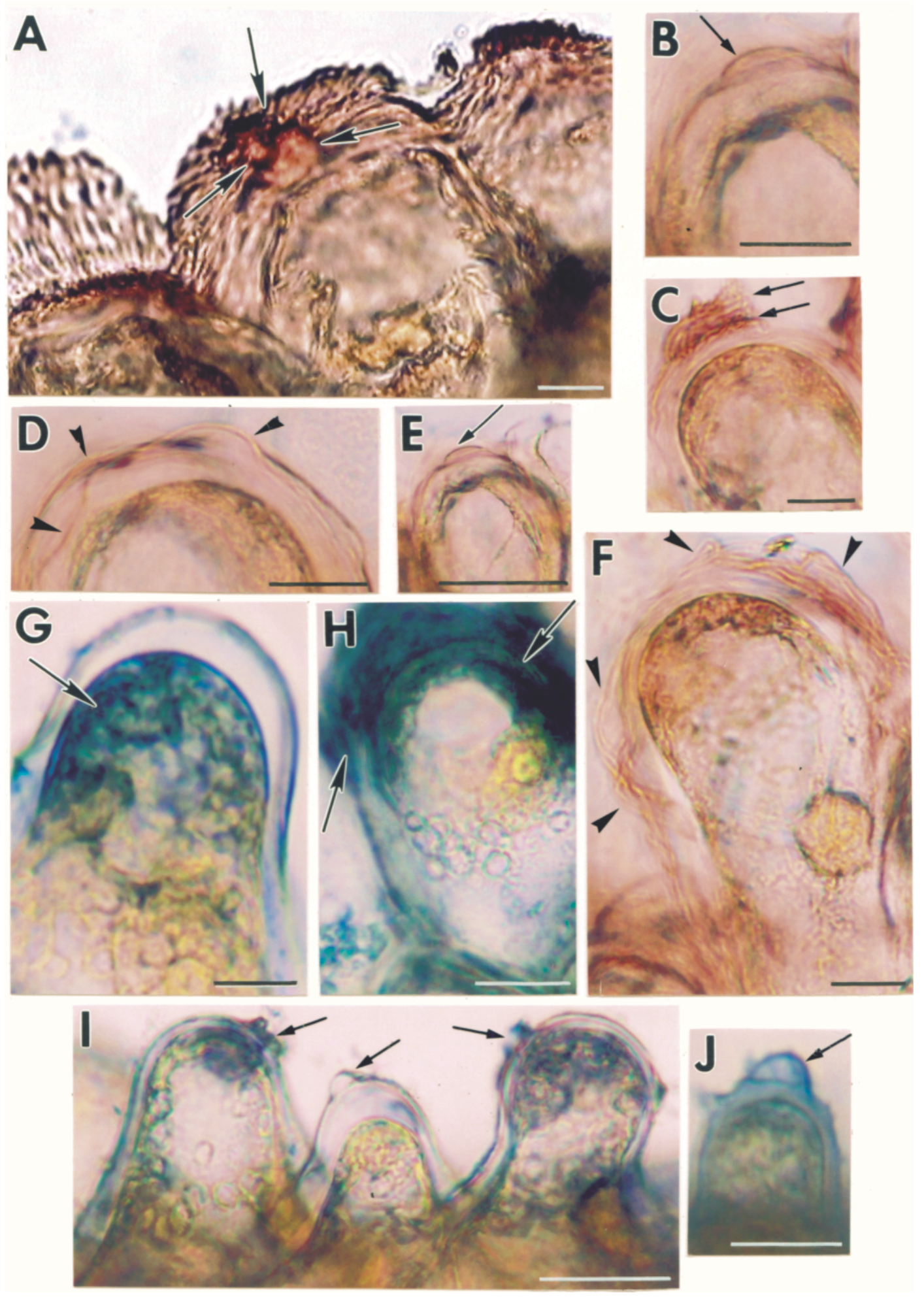

Fig. 5, A J. Fragments of the epidermis cells and glandular hairs after the use of lipid detecting tests. A Epidermis cells with the striatae, ripped cuticle and secretion droplets on the top (arrow). B F Top parts of the hairs with protruding cuticle (arrowheads) and secretion droplets (arrows); G J In cytoplasm, cell wall and on the hair surface visible dark blue concentrations of secretion (arrows). Treatment: A F Sudan III; G J Sudan black B. A D bars $10 \mu$ m; F H bars $20 \mu \mathrm{m} ; \mathrm{E}, \mathrm{I}, \mathrm{J}$ bars $50 \mu \mathrm{m}$. 

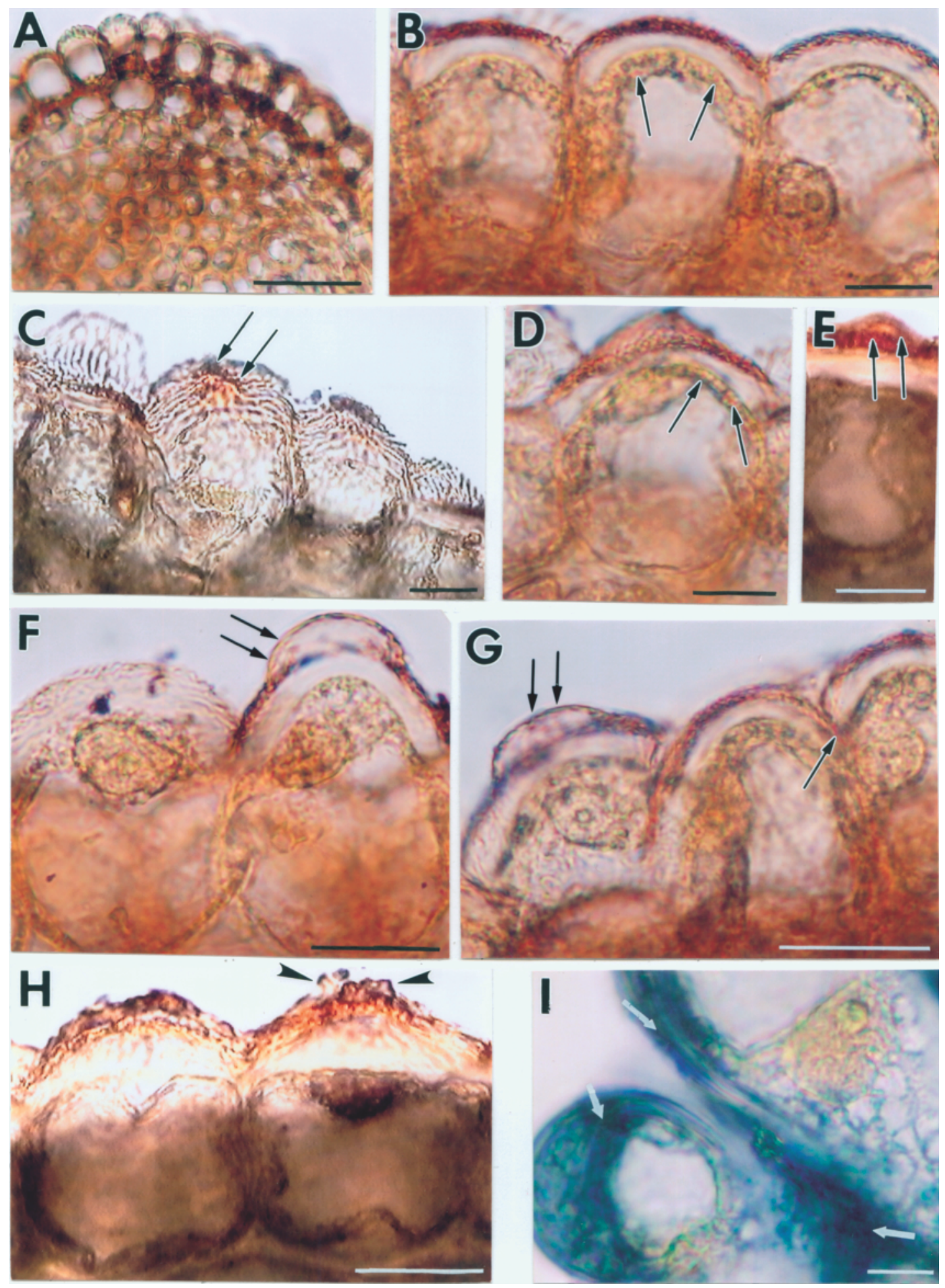

Fig. 6. A I. Epidermis cells on the cross sections of the lower part of the filament. A Fragment of the cross section; B H Cuticle on the cells surface with the striatae ornamentation, prominent cuticle with accumulated secretion (double arrow), ripped cuticle (arrowhead), enlarged nuclei are situated in the different parts of the cells, in cytoplasm visible lipid droplets (arrows). I Fragments of the hairs with lipid secretion turned dark blue (white arrows). Treatment: A H Sudan III; I Sudan black B. A bar $100 \mu \mathrm{m}$; B I bars $20 \mu \mathrm{m}$. 

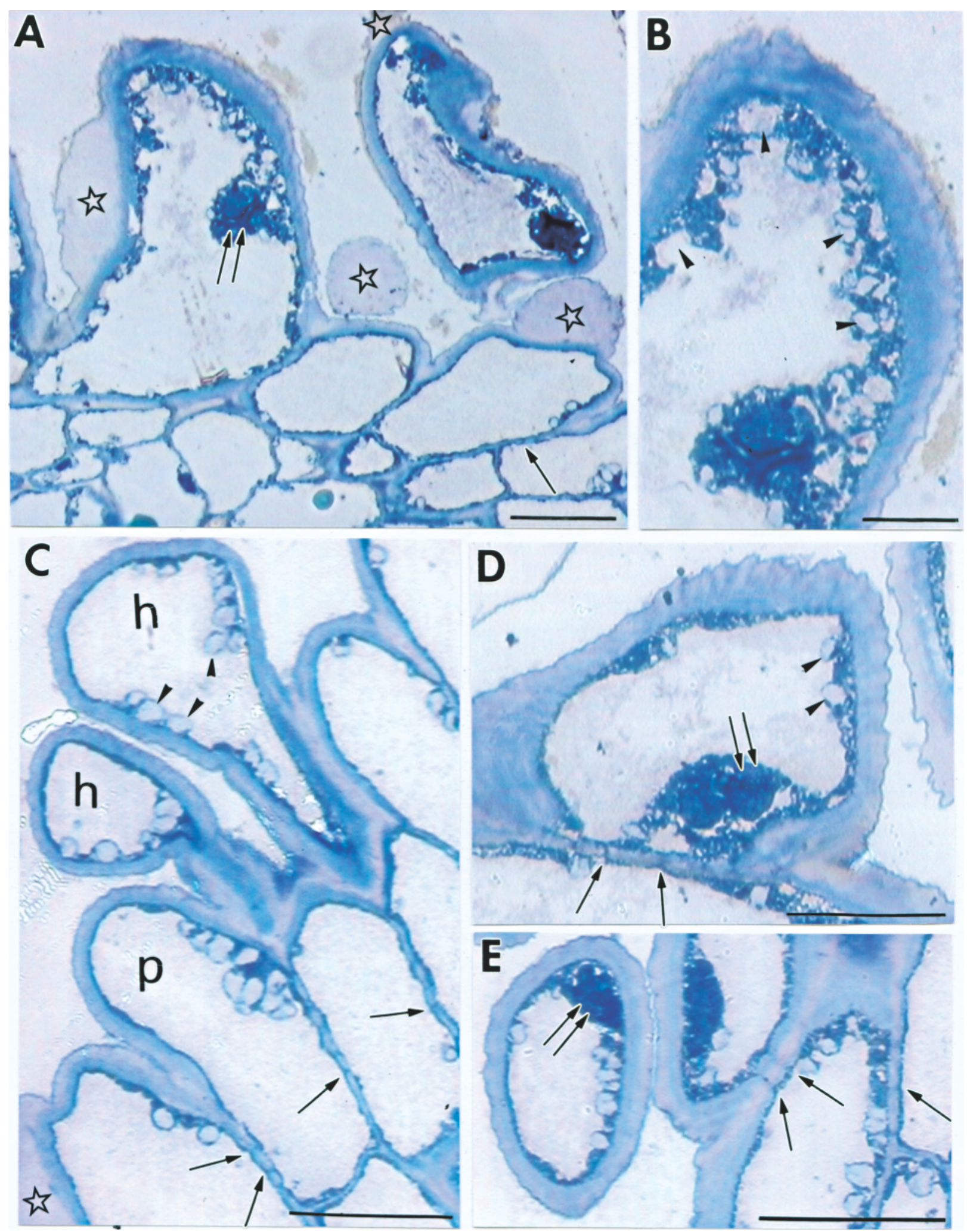

Fig. 7, A E. Glandular hairs and papilliose cells on the cross sections of the wider part of filament (semi thin sections). A C Longitudinal sections of the hairs; C Glandular hairs (h) and papiliose cells (p) on the longitudinal sections; E Cross sections of the hairs, visible thick outer cell walls, big vesicles with secretion limited with the protruding cuticular layer (asterisks), piths in the cell walls (arrows), small vacuoles in the cytoplasm (arrowheads) and lobed nuclei (double arrows). A, C E bars $50 \mu \mathrm{m}$; B bar $20 \mu \mathrm{m}$. 
Sudan III the droplets of lipid secretion observed also in cytoplasm (Fig. 6B), and after treating with Sudan B the dark blue areas were noticed in the cytoplasm and the cell wall (Figs. 5G-I; 6I).

At the surface of the club-shaped hairs we observed ripped (Fig. 5C) and protruding irregularly cuticle (Fig. 5B, D, F) as a result of secretion and accumulation in various places of the walls of hairs of lipid substances. Traces of protruding and breaking cuticle correspond with damages of the surface of papillae (Figs. 2B, C, E) (SEM). Also in the semi-thin preparations, on the walls of the cells of epidermis, very large vesicles with elicitor, limited by layer of protruding cuticle (Fig. 7A) were observed.

\section{DISCUSSION}

In the staminal filaments of Asphodelus aestivus presence of osmophores secreting scented substances were observed. The secreting epithelium covered the lower, widened and flattened part of the staminal filaments. The osmophores consists of isodiametric cells of epidermis, papillose cells, and unicellular, mostly club-shaped hairs. In these cells large central vacuoles were observed as well as numerous small vacuoles present in cytoplasm, which enlarge during the emission of secretion and divide the cytoplasm into characteristic net-like strips. The greatly dispersed vacuom in the cells of osmophores was observed by Vogel (1990). In the cytoplasm we also noticed colored drops of lipid elicitor. The numerous secretion vesicles with the lipid substances were observed in the osmophore cells of other species by many researchers (Stern et al. 1987, Vogel 1990, Stpiczyńska 1993, 2001).

In Asphodelus aestivus the secretion was temporarily accumulated uppermost on the surface of the isodiametric cells of epidermis and uppermost or sideways on the surface of the papillae and hairs in the vesicles between the cuticle and cellulose wall. Layer of secreted substance on the surface of the cells of epidermis in other plants was also observed by Stern et al. (1987), Vogel (1990) and Ascensão et al. (2005). In Asphodelus aestivus after emission of secretion, the cuticle irregularly protrude from the remaining part of the cell wall, and in dry material (SEM) numerous round traces of stretched and broken cuticle were observed.

In osmophores of many other plant species presence of starch grains was found (Vogel 1990; Teixeira et al. 2004; A scensão et al. 2005). In the species studied in this research, in the cells of epithelium and subepidermal layers the presence of starch was not noticed. The lack of starch in the osmophore plastids Cypripedium is also reported by $\mathrm{Swanson}$ et al. (1980), by Platanthera Vogel (1990), and by Gymnadenia S tpiczyńska (2001).
In the subepidermal layers of the staminal filaments Asphodelus aestivus a well developed system of intercellular spaces was present. However, larger nuclei, starch content, or lipid substances, which could indicate their pertinence to osmophoric layers of parenchyma, were not observed.

It was indicated, however that the cells of the epidermis of the widened filaments, regardless of the outside structure had traits of osmophores. It was found that transmigration of secretion through the cell wall can take place in many areas of the same hair. This is where the substantial convex areas of the cuticle associated with the accumulation of the secreted substance are present after which the cuticle irregularly protrudes from the wall on a large surface.

Further studies of the osmophores of Asphodelus aestivus associated with the ultrastructure of the cells are foreseen.

\section{REFERENCES}

Ascensão L, Francisco A., Cotrim H., Pais M. S., 2005. Comparative structure of the labellum in Ophrys fusca and O. lutea (Orchidaceae). Am. J. Bot. 92: 10591067.

Effmert U., Grosse J., Rose U. S. R., Ehrig F., Kagi R., Piechulla B., 2005.Volatile composition, emission pattern, and localization of floral scent emission in Mirabilis jalapa (Nyctaginaceae). Am. J. Bot. 92(1): 212.

Esau K., 1973. Anatomia roślin. PWRiL, Warszawa.

Faegri K., Van der Pij1 L., 1971. The Principles of Pollination Ecology. Pergamon Press, Oxford. 291.

Kolosova N., Sherman D., Karlson D., Dudareva N., 2001. Cellular and subcellular localization of S adenosyl L methionine: benzoic acid carboxyl methyltransferase, the enzyme responsible for biosynthesis of the volatile ester methylbenzoate in snapdragon flowers. Plant Physiol. 126(3): 956964.

Lex T., 1954. Duftmale an Blüten. Zeitschrift für vergleichende Physiologie. 36: 212234.

Nevalainen J. J., Laitio M., Lindgren I., 1972. Periodic acid Schiff (PAS) staining of Epon embedded tissues for light microscopy. Acta Histochem. 42: 230233.

Passarelli L., Bruzzone L., 2004. Significance of floral colour and scent in three Solanum sect. Cyphomandropsis species (Solanaceae) with different floral rewards. Australian Journal of Botany 52(5): 659667.

Raguso R.A., Pichersky E., 1999. A day in the life of a linalool molecule: chemical communication in a plant pollinator system. Part 1: Linalool biosynthesis in flowering plants. Plant Species Biol. 14: 95120.

Slater A. T., Calder D. M., 1988. The pollination biology The pollination biology of Dendrobium speciosum Smith: a case of false advertising? Aus. J. Bot. 36(2): 145158.

Stern W. L., Curry K. J., Pridgeon A. M., 1987. Osmo phores of Stanhopea (Orchidaceae). Am. J. Bot. 74: 13231331. 
Stpiczyńska M., 1993. Anatomy and ultrastructure of osmophores of Cymbidium tracyanum Rolfe (Orchidaceae). Acta Soc. Bot. Pol. 62(1/2): 59.

Stpiczyńska. M., 2001. Osmophores of the fragrant orchid Gymnadenia conopsea L. (Orchidaceae). Acta Soc. Bot. Pol. 70(2): 9196.

Swanson E. S., Cunningham W. P., Holman R. T., 1980. Ultrastructure of Glandular Ovarian Trichomes of Cypripedium calceolus and C. reginae (Orchidaceae). Am. J. Bot. 67(5): 784789.

Teixeira S. P, Borba E.L, Semir J., (2004). Lip anatomy and its implications for the pollination mechanisms of Bulbophyllum species (Orchidaceae). Ann. Bot. 93(5): 499505.

Vogel S., 1990. The role of scent glands in pollination: on the structure and function of osmophores. Amerind, New Delhi, India.

Vogel S., Hadacek F., 2004. Contributions to the functional anatomy and biology of Nelumbo nucifera (Nelumbona ceae). III. An ecological reappraisal of floral organs. Plant Syst. Evol. 249(3/4): 173189.

Weryszko Chmielewska E., Sawidis T., Piotrowska K., 2006. Anatomy and ultrastructure of floral nectaries of Asphodelus aestivus Brot. (Asphodelaceae). Acta Agrobot. 59(2): 2942.

Weryszko Chmielewska E., Stpiczyńska M., 1995 Osmo phores of Amorphophallus rivieri Durieu (Araceae). Acta Soc. Bot. Pol. 64(2): 121129.

\section{Mikromorfologia i cechy histochemiczne osmoforów pręcikowych w kwiatach Asphodelus aestivus Brot.}

\section{Streszczenie}

Przeprowadzone badania dotyczyły mikromorfologii powierzchni komórek epidermy i cech histologicznych nitek pręcikowia Asphodelus aestivus Brot. Strukturę nitek pręcikowych analizowano W mikroskopie świetlnym (LM) przy użyciu różnych technik histochemicznych. Morfologię powierzchni epidermy nitek pręcikowia obserwowano w skaningowym mikroskopie elektronowym (SEM).

Nitki pręcików Asphodelus aestivus zrastają się bazalną częścią odosiowej powierzchni z listkami okwiatu. Ich dolna, rozszerzona i spłaszczona część otacza zalążnię. Epiderma nitek pręcikowia wytwarza komórki brodawkowate i jednokomórkowe włoski różnej wielkości. W szczytowej części tych struktur obserwowano w SEM koliste ślady w obrębie kutykuli po emisji wydzieliny. Zewnętrzna, wypukła ściana izodiametrycznych komórek epidermy, papilli i włosków była znacznie grubsza od pozostałych ścian. Była pokryta kutykulą o różnej ornamentacji. Komórki wytwarzające papille i włoski miały dużą, centralnie położoną wakuolę i cienką warstwę cytoplazmy z licznymi małymi wakuolami oraz duże często płatowate jądra komórkowe. W protoplastach tych komórek stwierdzono obecność plastydów i kropel lipidowych. W czasie sekrecji wydzieliny między ścianą a kutykulą komórek epidermy tworzyły się pęcherzykowate uwypuklenia, w których była akumulowana wydzielona substancja. Pod koniec sekrecji na powierzchni papilli, włosków i innych komórek epidermy obserwowano odstającą nieregularnie kutykulę. Stwierdzono, że w skład osmoforów położonych na pręcikach w kwiatach Asphodelus aestivus wchodzą papille, włoski i komórki epidermy nie wytwarzające papilli. 